\title{
CONSTITUTIONAL LAW CONFLICTS AND WORKMEN'S COMPENSATION
}

\section{ARTHUR LARSON*}

It is a fact familiar to conflict of laws scholars that an unusually high proportion of landmark conflicts decisions have been supplied by workmen's compensation cases-such as Bradford Electric Light Co. v. Clapper, ${ }^{1}$ Alaska Packers Association v. Industrial Accident Commission, ${ }^{2}$ Pacific Employers Insurance Co. v. Industrial Accident Commission, ${ }^{3}$ Magnolia Petroleum Co. v. Hunt ${ }^{4}$ Industrial Commission v. McCartin, ${ }^{5}$ Carroll v. Lanza, ${ }^{6}$ and Crider v. Zurich Insurance $\mathrm{Co}^{7}$ Indeed, one could write a general account of the remarkable metamorphosis of conflicts under constitutional law, from conceptualism to pragmatism, from full faith and credit to legitimate state interests, from rigidity to permissiveness, without ever having to go beyond workmen's compensation cases for illustrative authority at each key point. Perhaps as effective a way as any to explain this phenomenon is simply to cite the fact situation in Daniels $v$. Trailer Transport Co. ${ }^{8}$ Claimant, a resident of lllinois, executed a contract of employment in Texas with an employer whose home office was in Michigan, but who engaged in operations in various states. It was stipulated that the workmen's compensation law of Michigan should apply. The employee then worked for the employer in several states, not including Michigan, Illinois, or Texas, before suffering a compensable accident in Tennessee.

This sort of four-state tangle, which almost sounds as if it had been invented for an examination question in Conflict of Laws, is by no means unusual, what with truck, bus and air lines, construction companies, and many other industries operating on a nationwide or

* Professor of Law, Duke University, and Director of Rule of Law Research Center. A.B. 1931, LL.D. 1953, Augustana College; M.A. (Juris.) 1938, D.C.L. 1957, Oxford University.

I. 286 U.S. 145 (1932).

THE FOLLOWING HEREINAFTER CITATION IS USED IN THIS ARTICLE:

A. LARSON, THE LAW OF WORKMEN's COMPENSATION (1952) [hereinafter cited as LARSON].

2. 294 U.S. 532 (1935).

3. 306 U.S. 493 (1939).

4. 320 U.S. 430 (1943).

5. 330 U.S. 622 (1947).

6. 349 U.S. 408 (1955).

7. 380 U.S. 39 (1965).

8. 327 Mich. 525, 42 N.W.2d 828 (1950) (Michigan statute held inapplicable). 
even worldwide basis, drawing their employees from many states, contracting with them at the home office or at branch headquarters, and sending them to work in different states and countries, often after trying to contrive a private contract that will ensure the applicability of a single named compensation statute.

If there were substantial uniformity between the different statutes, the problem would be less acute; but the maximum available benefits may vary from, for example, a total permanent disability award limited to $\$ 12,500$, to a payment of $\$ 150$ a week for life, the cumulative value of which in the case of a person totally disabled in his youth and living to a ripe old age could conceivably exceed $\$ 400,000$. Moreover, when the compensation claim is made in one state and a third party damage action is brought in another, lack of uniformity on the question of what third persons may be sued $^{9}$ at common law by a compensation claimant or subrogee frequently means that the very existence of the right of action depends on the treatment of the conflicts problem.

\section{Crider v. Zurich Insurance Co. and the "special remedy" rule}

At the outset it must be stressed that the issue in workmen's compensation cases is always one of conflict of laws, not choice of law, when what is at stake is an affirmative claim for benefits, as distinguished from a related damage suit. This is the necessary result of the rule that a claim, to be valid, must follow the designated procedure, that only the special tribunal created by the particular state can administer claims thereunder, and that rights created by the compensation act of one state cannot ordinarily be enforced in another state or in a federal court. ${ }^{10}$

9. LARSON $\S \S 72,88.20$.

10. Green v. J.A. Jones Constr. Co., 161 F.2d 359 (5th Cir. 1947) [1t was here held that a Mississippi federal district court does not have jurisdiction over an action to enforce the Georgia Workmen's Compensation Act, since the Georgia Act provided for an exclusive administrative remedy. The court, at 359, said: "[W]here the provision for the liability claimed is coupled with a provision for a special remedy to be afforded not by a court but by a commission, that remedy and that alone must be employed and resort to court action may not be had for relief." This language is almost identical to the language used by the United States Supreme Court in Tennessee Coal Co. v. George, 233 U.S. 354 (1914).]; Elliott v. De Soto Crude Oil Purchasing Corp., 20 F. Supp. 743 (W.D. La. 1937); Logan v. Missouri Valley Bridge \& Iron Co., 157 Ark. 528, 249 S.W. 21 (1923); Woodham v. Travelers Ins. Co., 161 So. 2d 368 (La. App. 1964) [Claimant was hired and injured in Mississippi by an employer who was licensed to do business in Louisiana. The court held that only the Mississippi Act could apply, and Louisiana could not enforce the Mississippi Act, since it was administered by a commission.]; Bethlehem Stcel 
Although this general proposition has been largely unquestioned for many years, the appearance in 1965 of the Supreme Court decision in Crider v. Zurich Insurance Co." has been the occasion for some reexamination of the rule. Claimant was employed by a Georgia corporation in Alabama where he resided. He was injured in Alabama while working under the Georgia Workmen's Compensation Act. The Supreme Court held that the Alabama courts could apply the Georgia Act without violating the full faith and credit clause.

The actual holding of this case is not as broad as might first appear. Indeed, a close examination of the precise point decided reveals that the direct effect of the case may be extremely narrow. The peculiar and limited character of the holding originates in the fact that the insurance carrier and employer did not defend the case in Alabama. Judgment was taken by default. The claimant then sought to enforce the judgment in the Federal District Court for the Northern District of Alabama, jurisdiction being based on diversity of citizenship. The court granted carrier's motion to dismiss, and the Fifth Circuit affirmed. ${ }^{2}$

The issue was thus restricted at the outset by the fact that it was raised by a collateral attack upon an Alabama judgment. Under Alabama law, as a result of the rather remarkable holding of Singleton v. Hope Engineering Co. ${ }^{13}$ the rule is that the Alabama courts do not have subject-matter jurisdiction to enforce the Georgia Workmen's Compensation Act. There is nothing remarkable in the Singleton result; what is remarkable is putting the holding on the

Co. v. Payne, 183 So. 2d 912 (Miss. 1966) [Claimant allegedly suffered compensable injuries in North Dakota and Louisiana, and brought suit for compensation benefits under the laws of these states in Mississippi. The court found that the Louisiana claim was barred by the Louisiana statute of limitations, that the North Dakota system was administrative rather than judicial, and that therefore Mississippi could not award benefits under the provisions of either system.]; Davis v. Swift \& Co., 175 Tenn. 210,133 S.W.2d 483 (1939) [The plaintiff's employer induced the plaintiff to leave Florida, the place of injury, and to return to his home in Tennessee, promising to continue payments under the Florida Act. When the employer discontinued payment, plaintiff sued in a Tennessee court. 1t was held that the Tennessee court could grant no relief, since administration of the Florida Act was entrusted to a commission.]; Greiner v. Alta Crest Farms, 1nc., 115 Vt. 324, 58 A.2d 884 (1948). Contra, Employers' Liab. Assur. Corp. v. IVarren, 172 Tenn. 403, 112 S.W.2d 837 (1938). See also RestatemENT (SECOND) OF Conflict OF LAws $\S 85$ (1971): “A state will not exercise judicial jurisdiction if it cannot provide appropriate relief."

11. 380 U.S. 39 (1965).

12. 324 F.2d 499 (5th Cir. 1963).

13. 223 Ala. 538,137 So. 441 (1931). 
ground of lack of subject-matter jurisdiction, in view of the fact that the injury and the claimant were both located in the jurisdiction. However, once it is said that the court does not have subject-matter jurisdiction, it becomes possible under Alabama law to go on and say that the judgment entered in the absence of such jurisdiction is subject to collateral attack. ${ }^{14}$ This is apparently what the federal district court did in this instance.

The Supreme Court, however, took the view that the district court and the circuit court of appeals must, erroneously, have reached the conclusions they adopted on the theory that the full faith and credit clause required such a result. ${ }^{15}$ The dissent by Justice Goldberg, with whom Justice Harlan and Justice Stewart joined, argued strongly that the lower federal courts had not been impelled by the full faith and credit clause to reach their conclusions, and in fact, that any reference to constitutional questions had been conspicuously lacking throughout. If the attack on the judgment in the district court had been based on the full faith and credit clause, it would immediately have encountered the general rule that a judgment in a state court cannot be collaterally attacked on full faith and credit grounds. ${ }^{16}$ Since there was no reference to this rule, it seems clear that the collateral attack was possible only because the court, under diversity jurisdiction, was applying the Alabama rule mentioned above, under which collateral attack was possible because of the theory that subject-matter jurisdiction did not exist.

The reason, therefore, that the case need not have any wide practical significance is that no insurer or carrier hereafter will presumably make the mistake of allowing this kind of suit to go by default judgment, in the expectation of later attacking it collaterally in defense

14. See Romero v. Mattioh Constr. Co., 193 Pa. Super. 90, 163 A.2d 671 (1960). The claimant obtained a compensation judgment against the employer in the New Jersey courts by statutory service of process upon the Secretary of the New Jersey Compensation Bureau. In an action in the Pennsylvania court on the judgment, the employer contended that, since he had done no business in New Jersey, the statutory service of process was void. The court rcmanded, holding that the employer may raise the defense of "never accepting the privilege of engaging in work in New Jersey" to defeat the fundamental grounds on which New Jersey jurisdiction was originally established.

15. The court based this inference partly on the fact that the Fifth Circuit in its opinion at 324 F.2d 499 (1963), had felt itself bound by Green v. J.A. Jones Constr. Co., 161 F.2d 359 (5th Cir. 1947), which in turn had taken over almost verbatim the formulation of the doctrine in Tennessee Coal Co. v. George, 233 U.S. 354 (1914) which itself was based on the full faith and credit clause. See note 10 supra.

16. Morris v. Jones, 329 U.S. 545 (1947). 
to a suit based on the judgment. Assuming that a direct attack is made upon an attempt to apply the commission-based compensation law of State $A$ in the courts of State B, the direct attack would ordinarily succeed, not because the full faith and credit clause compels this result, but because it is compelled by considerations of sound judicial administration.

There is a strong practical reason which is more than adequate to account for these decisions ${ }^{17}$ quite apart from any constitutional considerations. In most acts administered by commissions, the substantive rights created by the workmen's compensation act involve more than a certain number of dollars. The purpose of commission administration is not merely to settle disputes and award sums of money, but also to maintain supervision over the entire process of seeing that the claimant receives the full benefits of the act, including medical care and rehabilitation, with whatever adjustments from time to time might become necessary. Suppose the workmen's compensation system of State $\mathrm{X}$ were of the most highly developed type, complete with an administrative director, constant supervision of lifetime benefits, continuous jurisdiction of the commission over the award, rehabilitation and vocational programs, reopening features, and so on. How could the courts of State Y purport to confer these benefits upon the claimant? The benefits are inextricably intertwined with the entire administrative process and cannot be separated from it. This is undoubtedly the practical reason for the holding that commissionadministered compensation acts will not be applied in foreign states.

The Supreme Court's opinion seems to indicate that it did not consider the matter in this light. If it had, the Court might well have devoted at least some attention to the problem whether there is a violation of full faith and credit when State $\mathrm{Y}$ purports to apply the statute of State $\mathrm{X}$ under circumstances in which it can do so only in piecemeal fashion, providing some of the benefits, but without the entire network of services-for example, supervision, qualifications, reopening possibilities. ${ }^{18}$

17. See cases cited note 10 supra. It should be noted that Green did not involve a holding by a federal court that one state cannot apply the compensation law of another state. Rather, it simply held that a federal court, exercising diversity jurisdiction, would not itself choose to apply the compensation law of the state when that compensation law by its terms was entrusted to the administration of a commission.

18. Cf. Pearson v. Northeast Airlines, Inc., 309 F.2d 553 (2d Cir. 1962), affg on rehearing, 307 F.2d 13I, cert. denied. 372 U.S. 912 (1963). 
In summary, Crider does not detract from the rule that only the designated tribunal can implement compensation rights. It merely says that this rule cannot be based upon the full faith and credit clause. Since, so far as can be ascertained, the rule in workmen's compensation cases never has been based upon the full faith and credit clause, and in any event need not be, the net change seems to be minimal.

The Supreme Court remanded the case to the court of appeals with instructions to reconsider it free of any possible compulsions stemming from the full faith and credit clause. The Fifth Circuit immediately reinstated its order, saying that it was never intended to be based on any such compulsion; and as to this reinstatement the Supreme Court denied certiorari, ${ }^{19}$ leaving matters largely where they were before the Court's Crider opinion.

Largely, but not quite entirely. For one thing, Crider, following a series of Supreme Court decisions abandoning at an accelerating rate constitutional dictation of answers to compensation conflicts questions, can be viewed as at least pounding one more nail in the coffin of the early rigid constitutional approach. In addition, Crider stimulated a wave of speculation by commentators as to whether the "special remedy" rule itself, apart from constitutional considerations, should not perhaps be modified in the interests of fairness and convenience to claimants. ${ }^{20}$ To be able to bring his action in his own state of residence rather than in the foreign state whose act is relied on would undoubtedly be more convenient in some cases to an injured workman. But -if for the moment we approach the matter on purely policy grounds-against this occasional convenience must be weighed the potential loss in divorcing the foreign state's substantive law from the machinery tailor-made to administer it. The point at which these commentators go wrong is in underestimating how "special" the special remedy afforded by a modern compensation act is. If there were no more to compensation administration than handing the claimant a sum of money and being done with him, the matter might be different. But a highly-developed compensation system does far more than that. It stays with the claimant from the moment of the

19. Crider v. Zurich Ins. Co., 348 F.2d 211 (5th Cir. 1965), cert. denied, 382 U.S. 1000 (1966).

20. See particularly: Greenspan, Crider v. Zurich Insurance Company: Decline of Conceptualism in the Conflict of Laws, 27 U. P1Tr. L. Rev. 49 (1965); Comment, Forum Commission Enforcement of Foreign Workmen's Compensation Acts, 34 U. CH1. L. REv. 177 (1966). 
accident to the time he is fully restored to normal earning capacity. This may involve supervising an ongoing rehabilitation program, perhaps changing or extending it, perhaps providing, repairing, and replacing prosthetic devices, and supplying vocational rehabilitation. Apart from rehabilitation, optimum compensation administration may require reopening of the award from time to time for change of condition or for other reasons. If dependency is involved, the widow's marital status may change, or eligible beneficiaries may be subtracted making it possible for others to be added. A claimant may come forward with a plan that will justify converting periodic payments to a lump sum, subject to the discretionary judgment of a commission and perhaps of a medical panel that this would serve the best interests of claimant's rehabilitation.

It is true that, under Pearson v. Northeast Airlines, ${ }^{21}$ it may be constitutionally permissible to adopt part of the law of another state without adopting it all. In Pearson the Second Circuit held that New York could, without offending the full faith and credit clause, apply the Massachusetts Wrongful Death Act to establish a substantive breach of duty by the airline, and then adopt New York's own measure of damages.

But, although Crider seems to hold that "piecemeal borrowing" of a foreign compensation statute might not necessarily be unconstitutional, such borrowing remains a violation of sound judicial administration and, in some instances, as when a state with primitive compensation administrative facilities purports to borrow piecemeal from a state with advanced and elaborate facilities, it is a flagrant breach of the principle that a substantive remedy intertwined with a specifically designed administrative system cannot be adequately afforded by a foreign court.

It is sometimes held that, if the compensation rights are not tied to any particular administrative procedure, but are enforceable generally by the courts of the home state, there is no such obstacle to their being enforced in the courts of another state, ${ }^{22}$ but the opposite hold-

21. 309 F.2d 553 (2d Cir. 1962), cert. denied, 372 U.S. 912 (1963).

22. Texas Pipe Line Co. v. Ware, 15 F.2d 171 (8th Cir.), cert. denied, 273 U.S. 742 (1926); Lindberg v. Southern Cas. Co., 15 F.2d 54 (S.D. Tex. 1926), affd sub nom. United Dredging Co. v. Lindberg, 18 F.2d 453 (5th Cir.), cert. denied, 274 U.S. 759 (1927); Floyd v. Vicksburg Cooperage Co., 156 Miss. 567, 126 So. 395 (1930). 
ing is equally common..$^{23}$ The essence of the question is not so much whether the administration of the act in the two states is by court or commission as whether the forum state can provide substantially all of the remedy guaranteed by the foreign statute. For example, the Mississippi Supreme Court said, in granting relief under the Louisiana Act: "It is not necessary that the remedy shall be identical with that of the foreign jurisdiction. . . . It is only necessary . . . that we are able to do substantial justice between the parties under the rights existing by virtue of the foreign substantive law."24 But the potential injustice may take many forms, even when the comparison is between two court-administered laws. An obvious illustration is the unavailability of a comparable reopening procedure in the forum state. In Johnson v. Employers Liability Assurance Corporation, ${ }^{25}$ the court said that the test was whether "the law by which the right claimed must be determined is such that we can properly and intelligently administer it." ${ }^{26}$ The Texas court was being asked to apply the Louisiana court-administered act. The Louisiana statute permitted reopening to increase or diminish the award on a showing of change in condition. Since the Texas court had no such authority under Texas law, application of the Louisiana statute was refused.

By the same token, it does not follow that, because the laws of the forum state and foreign state are both commission-administered, the obstacle to statute-borrowing is surmounted. There may still be many important and valuable rights that the forum state could not provide, even if it could somehow assume administration of the claim through its commission. One commentator, recognizing the legal impediments to a direct filing of a claim with the commission of the forum state for statutory benefits provided by a foreign statute, has suggested that the claimant might first apply to the courts of the forum state, which in turn would delegate the handling of the claim to the compensation commission of the forum state. ${ }^{27}$ Without going

23. Martin v. Kennecott Copper Corp., 252 F. 207 (W.D. Wash. 1918); Mosely v. Empire Gas \& Fuel Co., 313 Mo. 225, 281 S.W. 762 (1926); Consolidated Underwriters v. King, 160 Tex. 18, 325 S.IV.2d 127, cert. denied, 361 U.S. 198 (1959) (holding that although both the Texas and Louisiana acts are court-administered, Texas will not enforce rights created under the Louisiana act).

24. Floyd v. Vicksburg Cooperage Co., 156 Miss. 567, 579-80, 126 So. 395, 398 (1930).

25. 99 S. W.2d 979 (Tex. Civ. App. 1936).

26. Id. at 981 . See the more recent case of Consolidated Underwriters v. King, 160 Tex. 18, 325 S.W.2d 127, cert. denied, 361 U.S. 198 (1959), which also involved a refusal of Texas to apply the Louisiana law.

27. Comment, Forum Commission Enforcement of Foreign Workmen's Compensation Acts, supra note 20. 
into the formidable task of ascertaining on a state-by-state basis how this could be legally accomplished, one may only observe that the device, even if available, would not in a significant proportion of cases solve the basic difficulty, which is the disparity between the remedies that can be afforded even as between commission-administered systems.

The discussion of any serious inroads into the "special remedy" rule proves to be rather academic when set against the realities of compensation practice. If exceptions are to be made to the rule, they would almost certainly have to be on a case-by-case basis. The court would in every instance have to undertake a definitive analysis of the compensation systems of the two states, analyze their similarities and differences, try to weigh the importance of the differences, perhaps try to guess which differences would be significant in the particular case-and then in turn weigh these differences against the value of allowing claimant the convenience of proceeding in his own state. It seems most unlikely that courts will be willing to shoulder this task merely in order to let the claimant bring his claim closer to home. And as for delegating the case to the local commission, is a claimant going to take on himself the staggering task of achieving not one but two or three ground-breaking innovations in compensation law and procedure, with all the appellate litigation this would entail, when he could get a routine award without litigation by following orthodox procedures?

The statutes of Arizona, ${ }^{28}$ Vermont, ${ }^{29}$ and Hawaii ${ }^{30}$ expressly permit rights created under the acts of other states to be enforced by their courts or commissions, but no decisional law has grown up showing how this can be done if the filing of a claim with a specified tribunal in the other state is a condition precedent to recovery. Indeed, Vermont refused to use this express statutory power when asked to apply the compensation law of Massachusetts, saying that "the remedy is an integral part of the right given and the latter has no existence separate and apart from the former." ${ }^{\prime 31}$ Idaho had such a statute ${ }^{32}$ but repealed it in 1963, and substituted a statute empowering the governor to enter into reciprocal arrangements with other states..$^{33}$ If anything

\footnotetext{
28. ARiz. Rev. Stat. ANN. § 23-904(B) (1956).

29. VT. Stat. ANN. tit. 21, \&620 (1967).

30. Hawall Rev. Laws § 386-6 (1968).

31. Grenier v. Alta Crest Farms, Inc., II5 Vt. 324, 58 A.2d 884 (1948).

32. Ch. 81, § 62, [1917] Idaho Sess. Laws 252.

33. IDAHo CODE ANN. $§ 72-619$ (Supp. 1969).
} 
is to be done to change the handling of this problem, the Idaho approach of authorizing ad hoc mutual arrangements may well be the most promising, since in any such plan the satisfactory meshing and balancing of rights under the two state systems could be thought out and worked out in advance.

\section{Successive Awards in Different States}

The development of the central conflicts problem is here divided into two steps: first, a demonstration that more than one statute can constitutionally apply to the same injury, and more than one award can be made so long as deduction is made for a prior award - the purpose of this demonstration being to show that the essence of the compensation conflicts question is not whether State $\mathrm{A}$ or $\mathrm{B}$ has the right, to the exclusion of the other, to apply its statute, but whether any given state has a sufficient interest in the case to justify applying its statute; and second, an examination of the question, "when can a state constitutionally apply its statute to a particular work injury?" with the conclusion that any state having a legitimate social interest in the injury and its effects on the workman, the employer, or the community can apply its statute without violating its obligation to give full faith and credit to the statutes of other states also having an interest. ${ }^{34}$

An appraisal of the present rule on successive awards in different states must take the form of an analysis of two Supreme Court decisions, Industrial Commission v. McCartin ${ }^{35}$ and Magnolia Petroleum Co. v. Hunt.$^{36} \mathrm{It}$ is now generally accepted that McCartin, in practical effect, has recognized the principle of successive awards and thereby discredited Magnolia, which had held on its facts that a prior Texas award was a constitutional bar to an award in Louisiana of the amount by which the Louisiana benefits exceeded those allowed by Texas.

Since, however, McCartin did not expressly overrule Magnolia, it is necessary to scrutinize the two opinions with some care, to see

34. Since this article is concerned only with constitutional issues, it does not reach the third question, which would be: "to what extent have the states in fact applied their statutes to extraterritorial injuries, within the permissible constitutional limits?" For a detailed state-bystate treatment of this question, showing the relative importance of such factors as place of contracting, place of injury and place of employment relation in the statutes and decisions of the different states, see LARSON $\$ 87$.

35. 330 U.S. 622 (1947).

36. 320 U.S. 430 (1943). 
whether $M c$ Cartin has indeed established a successive-award principle of general applicability.

Prior to McCartin, state courts, with virtual unanimity, had held or assumed that a prior award under the laws of another state was no bar to an award under local law made in accordance with the local law's own standards of applicability. ${ }^{37}$ There was always, of course, the understanding that the claimant could not have a complete double recovery but must deduct from his present recovery the amount of the prior award.

Then, in 1943, an oil field laborer, whose supplementary award in Louisiana, after a Texas award, had been sustained by the Louisiana appellate courts, appeared pro se to defend the Louisiana award against constitutional attack in the Supreme Court. His failure gave us Magnolia, a five-to-four decision with two dissenting opinions. The rationale of the holding was that "in Texas, a compensation award . . . is explicitly made by statute in lieu of any other recovery" for the same injury; the award therefore became res judicata and was entitled to full faith and credit in other jurisdictions like any judgment. The case evoked widespread controversy, with many writers deploring the new turn of events and favoring the dissenting views. ${ }^{38}$

Four years later, McCartin, in which the Supreme Court of Wisconsin, on the strength of the Magnolia doctrine, had denied a supplementary recovery in Wisconsin ${ }^{39}$ after an llinois award, reached the Supreme Court. Here an lllinois resident had made a contract of employment with an Illinois employer in Illinois, pursuant to which he did some work in Wisconsin, in the course of which he was injured. $\mathrm{He}$ began compensation proceedings in both states. While the Wis-

37. Migues' Case, 281 Mass. 373, 183 N.E. 847 (1933); McLaughlin's Case, 274 Mass. 217 , 174 N.E. 338 (1931); Sweet v. Austin Co., 12 N.J. Misc. 381,171 A. 684 (Sup. Ct. 1934); Hughey v. Ware, 34 N.M. 29, 276 P. 27 (1929); Bach v. Hampden Sales Ass'n, 293 N.Y. 847, 59 N.E.2d 439 (1944); Gilbert v. Des Lauriers Column Mould Co., 180 App. Div. 59, 167 N.Y. Supp. 274 (1917); Price v. Horton Motor Lines, Inc., 201 S.C. 484, 23 S.E.2d 744 (1942); Salvation Army v. Industrial Comm'n, 219 Wis. 343, 263 N.W. 349 (1935); Interstate Power Co. v. Industrial Comm'n, 203 Wis. 466, 234 N.W. 889 (1931); accord, RestatemeNT OF thE CONFLICT OF LAWS $\S 403$ (1934), as worded prior to the 1947 amendment. See note 42 infra.

38. Cheatham, Res Judicata and the Full Faith and Credit Clause: Magnolia Petroleum Co. v. Hunt, 44 Colum. L. Rev. 330 (1944); Freund, Chief Justice Stone and the Conflict of Laws, 59 HaRv. L. REv. 1210 (1946); Wolkin, Workmen's Compensation Award-Commonplace or Anomaly in Full Faith and Credit Pattern?, 92 U. PA. L. Rev. 401 (1944); 48 Dick. L. Rev. 194 (1944); 12 Geo. Wash. L. Rev. 487 (1944); 19 IND. L.J. 268 (1944); 17 S. CaL. L. ReV. 315 (1944); 18 TUL. L. REv. 509 (1944).

39. McCartin v. Industrial Comm'n, 248 Wis. 570,22 N.W.2d 522 (1946), rev'd. 330 U.S. 622 (1947). 
consin proceedings were pending, the Illinois commission issued a formal order approving a settlement agreement under Illinois law, and full payment was made under the order. The settlement contract, however, contained this sentence: "This settlement does not affect any rights that applicant may have under the Workmen's Compensation Act of the State of Wisconsin."

The Supreme Court, this time by unanimous vote, reinstated the Wisconsin award, distinguishing Magnolia. The primary ground of distinction was not, however, the express reservation of Wisconsin rights, but the absence in the Illinois statute or case law of an explicit prohibition against seeking additional or alternative relief under the laws of another state. Since the vast majority of compensation laws resemble the Illinois law in this respect, the decision has been taken to mean that for all practical purposes successive awards are now sanctioned. ${ }^{40}$ An amendment to the R'estatement of Conflict of Laws, designed to bring it into harmony with these decisions, ${ }^{41}$ adopted this interpretation by using the following language:

Award already had under the Workmen's Compensation Act of another state will not bar a proceeding under an applicable Act, unless the Act where the award was made was designed to preclude the recovery of an award under any other Act, but the amount paid on a prior award in another state will be credited on the second award. ${ }^{42}$

The crucial paragraph of the McCartin opinion, setting forth the reason for its conclusion-before anything is said about the express reservation in the contract - is sufficiently important to warrant quotation in full. The Court first quotes the Illinois exclusive-coverage clause and shows that it means in Illinois, as it does in practically every other state, that it is exclusive only in the sense that no other common law or statutory remedy under local law can be sought. The Court then goes on to say:

But there is nothing in the statute or in the decisions thereunder to indicate

40. Law review writers have almost unanimously interpreted the case as in effect overruling Magnolia for purposes of most state statutes. E.g., Price, State Jurisdiction Strikes Back, 19 N.Y.S.B.A. Bull. 199 (1947); 33 CORnell L.Q. 310 (1947); 60 HaRv. L. Rev. 993 (1947); $c$. 47 COLUM. L. REv. 846 (1947).

41. H. GoOdRich, CONFLict OF LAWS 289 (3d ed. 1949).

42. Restatement of Conflict of Laws $\S 403$ (Supp. 1943). The Restatement (Seconi) OF CONFLICT OF LAwS (1971), streamlines the statement of the rule to the following concise version:

$\S 182$. Effect of Two Statutes Governing Injury

Relief may be awarded under the workmen's compensation statute of a State of the

United States, although the statute of a sister State also is applicable. 
that it is completely exclusive, that it is designed to preclude any recovery by proceedings brought in another state for injuries received there in the course of an lllinois employment. And in light of the rule that workmen's compensation laws are to be liberally construed in furtherance of the purpose for which they were enacted, we should not readily intèrpret such a statute so as to cut off an employee's right to sue under other legislation passed for his benefit. Only some unmistakable language by a state legislature or judiciary would warrant our accepting such a construction. Especially is this true where the rights affected are those arising under legislation of another state and where the full faith and credit provision of the United States Constitution is brought into play.

We need not rest our decision, however, solely upon the absence of any provision or construction of the Illinois Workmen's Compensation Act forbidding an employee from seeking alternative or additional relief under the laws of another state. . . ..$^{43}$

At this point the Court discusses the express reservation of rights in Wisconsin, and concludes with these significant words: "the reservation spells out what we believe to be implicit in that $A c t$-namely, that an lllinois workmen's compensation award of the type here involved does not foreclose an additional award under the laws of another state." 44

Thus, the Court comes back to its basic and original ground, the nature of the statute itself, and says that the express reservation does no more than make abundantly clear what the act, of itself, must in any case be construed to mean.

The decisive question therefore becomes: Does the statute of a given state, as construed by "unmistakable language,". forbid relief under the laws of another state? One thing is clear. The normal exclusive-coverage clause does not have this effect, as the McCartin opinion itself recognizes. ${ }^{45}$ It is therefore important to observe, in

43. 330 U.S. at $627-28$ (citations omitted).

44. Id. at 630 (italics supplied). A more careful reading of the opinion at this point would have prevented the blunder in Bolton v. O'Connor, 114 F. Supp. 273 (S.D. Miss. 1953). The injury had occurred in Mississippi while the contract and residence location was Louisiana. Award was made in Mississippi, and later another award was sought in the U.S. District Court of Mississippi under Louisiana law. The court held the Magnolia rule applicable and distinguished McCartin on the sole ground that it was based on the stipulation between the parties.

45. Curiously, this elementary point was missed in Gasch v. Britton, 202 F.2d 356 (D.C. Cir. 1953). The court denied an award in the District after an award had been made in Maryland, on reasoning similar to that in Magnolia. The decision was based on the exclusive coverage provision relating to suit against the employer, that compensation shall be in lieu of "any and all rights of action whatsoever against any person whomsoever." The court made much of broad exclusiveness language from Victory Sparkler \& Specialty Co. v. Francks, 147 Md. 368, 128 A. 635 (Md. App. 1925), which however, was nothing more than a garden-variety holding that 
estimating the impact of McCartin on Magnolia, that the general exclusive coverage clause of Texas was not significantly different from that of Illinois. Texas did, however, have an express statutory provision, existing in very few other states, ${ }^{46}$ that if an employee first obtains compensation in another state for an out-of-state injury, he shall not thereafter get an award in Texas. This is not the present situation, but its reverse. The statute does not go on to say what the Magnolia opinion reads into it, that if the employee first obtains compensation in Texas he shall not thereafter get compensation outside of the state. The McCartin opinion seems to hold that this latter kind of prohibition must now appear in the statute or case law of a particular state if the Magnolia doctrine is to apply. On this interpretation of the McCartin rule, the Magnolia doctrine will apparently not apply even in Texas, once its statute and decisions are realistically construed. For it cannot be honestly said that anything in the Texas statutes or cases indicates that, when the sequence of events takes the form of a first award in Texas and a supplementary award in another state to bring the amount up to the standards of the latter, the State of Texas has any unconquerable aversion to the second award. All Texas says is that if some other state has first awarded compensation, it will add nothing to it in a later proceeding brought in Texas.

the compensation remedy is exclusive of common-law actions, and contained no language, unmistakable or other, on compensation awards in sister states. Here the employee lived in Maryland and was injured there, but the place of employment contract was in the District of Columbia.

46. See also Nevada Indus. Comm'n v. Underwood, 79 Nev. 496, 387 P.2d 663 (1963). Nevada law, Nev. Rev. Stat. $\S 616.530(1)$ (1963), provides that "any action or proceeding in any other state to recover any damages or compensation . . . shall constitute an irrcvocable waiver of any and all compensation" under the. Nevada laws. In Underwood the employee was hired in Idaho, was regularly employed in Nevada, but was killed in an accident in Utah. The widow filed a claim on which benefits were voluntarily paid under the Idaho compensation laws. The claim and payment were held to effect the irrevocable waiver, although the widow and the carrier had expressly agreed that the widow reserved her rights to claim death benefits under the Nevada law. Court dicta indicated that the quoted Nevada provision, referring to "action" and "damages," applied to common-law actions while "proceeding" and "compensation" applied to compensation claim proceedings, but an unsuccessful action or proceeding would not bar a subsequent claim under the Nevada law.

Arizona and Oregon provide that their own laws shall not apply to out-of-state injuries if the law of the state of injury applies. But this is quite a different matter, since it delimits local coverage generally and leaves nothing to the claimant's election. Similar in this respect is the Massachusetts provision, MASs. ANN. LAws ch. 152, § 26 (1965), that if an employee has elected, under a foreign act permitting such election, to remain under common-law rules generally, he shall not be covered by compensation in Massachusetts. This too is not an election, for the purpose of a particular injury, between coexisting rights, but a definition in advance of the basic scope of the local statute. 
The above analysis of the McCartin decision's effect has been confirmed, not only by the Restatement and almost all writers, but also by the great majority of subsequent cases. ${ }^{47}$ Cook v. Minneapolis

47. Agee v. Industrial Comm'n, 10 Ariz. App. 1, 455 P.2d 288 (1969) [Claimants, residents of Colorado who were hired in Colorado, were injured while on a trucking run in Arizona on their way to California, received lump sum settlements in Colorado, then sought recovery in Arizona and were entitled to the additional benefits provided by Arizona law.]; Lavoie's Case, 334 Mass. 403, 135 N.E.2d 750, cert. denied, 352 U.S. 927 (1956) [Rhode Island resident who made employment contract there and had received benefits under its act for an injury in Massachusetts held entitled to recovery under Massachusetts Act]; Schenkel v. Tower Builders Co., 380 Mich. 492, 157 N.W.2d 204 (1968) [Claimant, an Indiana resident, was employed by an Indiana corporation. While performing some work in Michigan he suffered disabling injuries. Compensation was applied for and recovered in Indiana, whose compensation act had been construed to be exclusive. Claimant then applied for and received additional benefits in Michigan, with credit being given for weekly payments made under the Indiana act. The court held that the acceptance of benefits under the Indiana act did not deprive Michigan of jurisdiction to award additional benefits under its act, and the full faith and credit clause of the United States Constitution did not bar the reeeipt of benefits under the act of one state after an award had been made in another state whose statute had been construed so as to be exclusive in application.]; Cook v. Minneapolis Bridge Constr. Co., 231 Minn. 433, 43 N.W.2d 792 (1950) (accord, Sorenson v. Standard Constr. Co., 238 Minn. 68, 55 N.W.2d 630 (1952)); Martin v. L \& A Contracting Co., 249 Miss. 441, 162 So. 2d 870 (1964) [Claimant was hired and regularly employed in Mississippi, but was injured in Florida. He was permitted to receive benefits under both the Florida and Mississippi compensation acts, deducting the amount of the first award from the second.]; Harrison Co. v. Norton, 244 Miss. 752, 146 So. 2d 327 (1962) [The claimant was employed under a contract made in Georgia to work in Mississippi, his residence and the place of injury. The carrier voluntarily made payments under the Georgia act and the claimant signed a Georgia form for "Final Compensation Settlement Receipt." He later brought a claim for permanent partial disability under the Mississippi act. The court reasoned that since the Mississippi act states that "No agreement by an employee to waive his right to compensation under this act shall be valid" (MISs. CODE ANN. § 6998-21 (1942) (Rec., § 15)), the "Final Receipt" of Georgia benefits did not bar a claim for Mississippi benefits. The court limited its decision to permitting a subsequent award, with credit for previous benefits paid, where the first award was granted under those state acts, such as Georgia, which do not specifically make an award in such state exclusive.]; Cramer v. State Concrete Corp., 39 N.J. 507, 189 A.2d 213 (1963) [An award under the New York act does not bar the claimant's right to claim benefits under the New Jersey act.]; Bowers v. American Bridge Co., 43 N.J. Super. 48, 127 A.2d 580, aff d, 24 N.J. 390, 132 A.2d 28 (1956) [New Jersey awarded benefits even though claimant had received payment in Pennsylvania, the place of injury, because the Pennsylvania act does not expressly exclude the right of recovery by an injured workman under the laws of any other state.]; Hudson v. Kingston Contracting Co., 58 N.J. Super. 455, 156 A.2d 491 (Mercer County Ct. 1959) [The deceased employee was a resident of Pennsylvania, the employer was domiciled in New Jersey, the place of contract was New Jersey, and the fatal accident occurred in Maryland. The widow was awarded $\$ 10,300$ under the Maryland compensation act but would receive $\$ 36,855.02$ under the New Jersey act. The court followed the McCartin case, holding that the Maryland act was exclusive only as to rights arising in Maryland. The difference in the awards was found to be so great as to be obnoxious to the policy of the New Jersey act, justifying the denial of full faith and credit. New Jersey benefits were awarded less the amount paid under the Maryland award. The court specifically followed the dissenting opinion in Gasch v. Britton, 202 F.2d 356, 361 (D.C. Cir. 1953) (Fahy, J., dissenting).]. Contra, Gasch v. Britton, 202 F.2d 356 (D.C. Cir. 1953); Bolton v. O'Connor, 114 F. Supp. 273 (S.D. Miss. 1953). 
Bridge Construction Co. ${ }^{48}$ is typical. Here, the employer's business, the employee's residence, and the place of contracting were in Minnesota, while the place of injury was in North Dakota. Benefits were first received under a North Dakota award. The exclusive-remedy clause of the North Dakota statute was admittedly even stronger than that of Illinois, for it provided that injured employees "shall have recourse ... only to the fund and not to the employer" and in another section that "the payment of compensation . . . shall be in lieu of any and all rights of action whatsoever." But since the statute did not explicitly preclude proceedings in another state, the Minnesota Supreme Court held that the McCartin rule permitted a supplementary award in Minnesota.

The Wisconsin Supreme Court, confronted with a similar set of facts, laid its stress on the question of finality of the first award. ${ }^{49} \mathrm{~A}$ prior award had been made in Montana for temporary total disability, and payments were still running at the time of the Wisconsin award. The Wisconsin court observed that the Montana board had continuing jurisdiction over the award, and could later determine any permanent disability that might exist. The first award was therefore not "final," and, under the Magnolia and McCartin opinions, not binding on other states. Whether the Magnolia decision meant final in this sense or final in the sense that the exact points covered by the particular award, being unappealed, ${ }^{50}$ could not be reopened, may be debatable; but this case in any event is one more illustration of the tendency toward constriction of the Magnolia rule.

Several variants of the successive-award problem may be mentioned in which the facts are much stronger than in McCartin and, in which, a fortiori, the first proceedings have been held not to prejudice the second. Several cases, both before and after McCartin,

48. 231 Minn. 433, 43 N.W.2d 792 (1950).

49. Spietz v. Industrial Comm'n, 251 Wis. 168, 28 N.W.2d 354 (1947). See also Plater v. Kane Warehouse Co., 241 Md. 462, 217 A.2d 102 (1966). Claimant regularly worked in Washington and Virginia, but was injured in Maryland. An award was made under the Maryland act, but claimant also filed under the Washingt on act, which provided greater benefits. Claimant was permitted to withdraw the Maryland claim, and proceed under the Washington act.

50. Chapman v. John St. John Drilling Co., 73 N.M. 261, 387 P.2d 462 (1963). The employee was awarded compensation in Texas, but appealed the award. He then filed a claim under the New Mexico act. The New Mexico Supreme Court avoided an application of the Magnolia doctrine by noting that, under Texas law, a case pending appeal is not res judicata, and therefore full faith and credit need not be given in New Mexico. Dismissal of the claim under the New Mexico act was reversed and remanded for hearing and determination. 
have held that a prior voluntary payment of compensation accepted by the employee under the laws of one state does not detract from the employee's statutory right to an award in another state, whether the agreement for compensation had received commission approval or not. ${ }^{51}$ Similarly, when the employee has not applied for compensation, but an award has been entered at the ex parte request of the employer, even Texas, with its express statute forbidding an award to one who has "elected to pursue his remedy" in another state, permits a supplementary award. ${ }^{52}$

51. Industrial Indem. Exch. v. Industrial Acc. Comm'n, 80 Cal. App. 2d 480, 182 P.2d 309 (1947); Industrial Track Builders of Am. v. LeMaster, 429 S.W.2d 403 (Ky. App. 1968) [Claimant received benefits under Indiana law, and then filed a claim in Kentucky. Shortly after injury claimant signed an agrcement with the carrier to receive benefits under the Indiana act, but took no further action, other than to receive benefits. The court held that since there was no express intention in the Indiana statute to have its law be exclusive, claimant was allowed to file a subsequent claim in Kentucky. However, the court indicated that in other circumstances, such as if claimant had knowingly filed a claim in Indiana and prosecuted it to a final award, he might not be entitled to later claim benefits in Kentucky.]; Cline v. Byrne Doors, Inc., 324 Mich. 540, 37 N.W.2d 630 (1949); Adams v. Emery Transp. Co., I5 Mich. App. 593, 167 N.W.2d 110 (1969) [Claimant worked for two trucking companies, which eventually merged. He was injured prior to the merger, and filed two compensation claims, one against one of the firms in lllinois, and the other in Michigan, against both firms. The Illinois claim was settled, including an agrcement that Illinois had exclusive jurisdiction, and that claimant would dismiss the Michigan proceedings. However, he did not do so, and eventually was awarded compensation against the employer who had not been involved in the Illinois claim. On appeal, the court held that although it was not satisfied with the result, the lllinois settlement would not bar further proceedings in Michigan, and the Michigan employer could not take credit for any amount paid pursuant to the Illinois decree, which involved a different employer.l; Miller v. National Chair Co., 19 N.J. Misc. 275, 18 A.2d 847 (Workmen's Comp. Bureau), affd, 127 N.J.L. 414, 22 A.2d 804 (Sup. Ct. 194I), affd per curiam, 129 N.J.L. 98, 28 A.2d 125 (Ct. Err. \& App. 1942); Della Vecchia v. World Scope Pub. Co., 64 N.J. Super. 33, 165 A.2d 872 (Essex County Ct. 1960) [The claimant was awarded New York compensation without appearance before the board, or service of process. He cashed the checks. The court held that his actions did not bar a claim under the more generous provisions of the New Jersey compensation act.]; Franklin v. George P. Livermore, Inc., 58 N.M. 349, 270 P.2d 983 (1954) (employment contract in New Mexico, injury in Texas; voluntary payments under Texas law not a waiver of any rights under New Mexico law). See also Reed v. Fish Eng'r Corp., 74 N.M. 45, 390 P.2d 283 (1964) [Payment of Utah benefits may toll the statute of limitations on filing a later claim for New Mexico benefits. Case remanded.]; $c f$. Pate v. Makin Drilling Co., 66 N.M. 402, 239 P.2d 121 (1960) [The employce of a New Mexico firm was sent from New Mexico to an oil field in Texas, where he was injured. Compensation was paid under the Texas compensation act until the benefits expired. The employee then filed claim for benefits under the New Mexico act. A lower court order requiring the employer to pay medical benefits was reversed. The court stated that the order would have bcen tantamount to a finding that the employer was also liable under the New Mexico act before such liability had been determined.].

52. Standard Acc. Ins. Co. v. Skidmore, 222 S.W.2d 344 (Tex. Civ. App. 1949). See Texas Employers' Ins. Ass'n v. Miller, 370 S.W.2d 12 (Tex. Civ. App. 1963). The Texas insurance carrier had the employce sign an "election of benefits" statement upon receipt of voluntarily 
Moreover, a denial of compensation in the first state does not necessitate a denial in the second state. ${ }^{53}$ Thus, when the employment contract was in Missouri and the injury in Arkansas, a denial of compensation in Arkansas, on the ground that claimant was an independent contractor, was held not to require a denial in Missouri, since each state may have its own interpretation of employee status. ${ }^{54}$

On the policy question whether the availability of the supplementary-award procedure is a desirable thing there is some difference of opinion. The argument against supplementary awards is that it may subject the employer and insurance carrier to repeated claims in different jurisdictions, protracting litigation and making it impossible for the employer and carrier to know with assurance when a claim has been fully satisfied. On the other side it is urged that employees typically are at a disadvantage in learning of their potential rights under various statutes of other states, especially since complex conflict-of-laws issues may sometimes be involved; hence they may quite forgivably make an unfortunate choice at the time of filing the first claim. ${ }^{55}$ It has even been suggested that representatives of the employer and insurer might influence the claimant toward such a choice..$^{56} \mathrm{ln}$ any case, the worst that can happen to the defendants, apart from the inconvenience mentioned above, is that they will have to pay no more than the highest compensation allowed by any single

paid Louisiana benefits. The court held that since he did not read the statement, and, having only a fourth grade education, did not understand what he was signing, the equitable rule abhorring elections would support a finding that no election had been made. Texas benefits award, supplemental to the Louisiana benefits, affirmed.

53. Smith v. Heine Safety Boiler Co., 119 Me. 552, 112 A. 516 (1921); Loudenslager v. Gorum, 355 Mo. 181, 195 S.W.2d 498, cert. denied, 331 U.S. 816 (1946); La Rue v. El Paso Natural Gas Co., 57 N.M. 93, 254 P.2d 1059 (1953) [Denial of award by Arizona, on the ground that the injury did not arise in the course of employment, was not a bar at a subsequent suit in New Mexico. Claimant was injured in Arizona, and resided there, but was employed in New Mexico and had been working there. This is significant since New Mexico will not allow a double recovery there for the same accident because it is contrary to public policy. Hughey $v$. Ware, 34 N.M. 29, 276 P. 27 (1929). Court stated that since claimant here had not received an award in Arizona this decision does not conflict with the Hughey case.]; Yoshi Ogino v. Black, 278 App. Div. 146, 104 N.Y.S.2d 82 (1951); Le Flore County Gas \& Elec. Co. v. Sickmann, 348 P.2d 312 (Okla. 1959) [Since the contract of hire was consummated in Oklahoma, a denial in Arkansas did not preclude an award in Oklahoma.]. (1946).

54. Loudenslager v. Gorum, 335 Mo. 181, 195 S.W.2d 498, cert. denied, 331 U.S. 816

55. Cheatham, supra note 38 , at 345.

56. H. Horowitz, Workmen's Compensation 39 (1944). See, e.g., Texas Employers' Ins. Ass'n v. Miller, 370 S.W.2d 12 (Tex. Civ. App. 1963). 
state ${ }^{57}$ having an applicable statute-which is the same amount that would always be payable if the claimant made the best-informed choice the first time.

\section{Constitutional Limits on Applicability of State Compensation Acts}

There are six grounds on which the applicability of a particular compensation act has been asserted. They are that the local state is the: Place where the injury occurred; Place of making the contract; Place where the employment relation exists or is carried out; Place where the industry is localized; Place where the employee resides; or Place whose statute the parties expressly adopted by contract.

When one of these falls within the local state, and some or all of the others occur in another state, the question arises whether the local state can apply its statute without being accused of denying full faith and credit to the statute of the other state. As matters now stand, it is clear that the state which was the locus of any one of the first three items-contract, injury or employment-and probably also of the next two-employee residence and business localization-can constitutionally apply its statute if it desires..$^{58}$

Until 1932, no one worried much about constitutional inhibitions on the applicability of compensation acts. Each state went ahead implementing its own theories on what features brought a given injury within its statute, with considerable diversity in the results. The contract, tort and employment theories all had their adherents; occa-

57. As to the possibility of double recovery in certain rare fact combinations, see LARSON $\S 85.70$.

58. THE RESTATEMENT (SECOND), supra note 42, adopts substantially the above analysis:

$\S 181$. Permissible Range of Territorial Application.

A State of the United States may consistently with the requirements of due process award relief to a person under its workmen's compensation statute, if

(a) the person is injured in the State, or

(b) the employment is principally located in the State, or

(c) the employer supervised the employee's activities from a place of business in the State, or

(d) the State is that of most significant relationship to the contract of employment with respect to the issue of workmen's compensation under the rules of $\S \S 187-188$ and 196 , or

(e) the parties have agreed in the contract of cmployment or otherwise that their rights should be determined under the workmen's compensation act of the State, or

(f) the State has some other reasonable relation to the occurrence, the parties and the employment.

The Reporter's Note states: "The rule of Suhdivisions (a) to (f) is supported by 2 LaRson, WORKMEN'S COMPENSATION 368-375 (1952)." 
sional unique combinations or theories appeared in other states; and some states did not even bother to explain what theory they were using.

The constitutional issue was injected by the 1932 Supreme Court decision in Bradford Electric Light Company v. Clapper. ${ }^{59}$ In this case all the incidents of the employment except the place of injury were within Vermont-making of the contract, principal place of employment, employee's residence, dependents' residence, and location of the employer's business. The decedent was killed while on temporary duty in New Hampshire. New Hampshire's law had the unique feature of allowing the claimant, after the injury or death, to elect either compensation or common-law remedies. The decedent's administratrix, before any proceedings were brought in Vermont, undertook a common-law action against the employer in New Hampshire. The defense was the provision of the Vermont act forbidding common-law suits when the injury fell within the terms of the Vermont compensation act.

The Supreme Court, reversing the district and circuit courts, held the New Hampshire action barred, since the full faith and credit clause applies to statutes of sister states as well as to judgments. The Court stressed that the interest of New Hampshire was only "casual," and concluded its opinion with this significant reservation:

We have no occasion to consider whether if the injured employee had been a resident of New Hampshire, or had been continuously employed there, or had left dependents there, recovery might validly have been permitted under New Hampshire law. ${ }^{60}$

lt should also be kept in mind, as this case is compared with later developments in the same area, that the thing barred was not conferral of affirmative compensation benefits in New Hampshire but escape from the compensation system into the common-law system by the choice of the New Hampshire statute.

As the law stood under Bradford, then, it was generally assumed that the single factor, locus of injury, was not enough to permit assertion of coverage by a state, at least when the employee's presence in the state was only incidental and temporary.

Three years later, Alaska Packers Association v. Industrial Acci-

59. 286 U.S. 145 (1932).

60. Id. at 163 . 
dent Commission ${ }^{61}$ began to develop the general test which inquires whether any incidents of the injury that are important and relevant to workmen's compensation fall within the local state. The injury in this case occurred in Alaska, but not, this time, on a temporary or incidental mission; the work was entirely to be performed within Alaska. But the contract was made in California,${ }^{62}$ which was the base of operations, transportation to and from Alaska was provided, and the employee was expected to return to California on completion of the work. The parties had agreed that the Alaska act should apply. The Supreme Court held that California's interest in the injury was sufficient to justify application of its own statute. Of special significance is the Court's observation that the claimant, if not compensated in California, might well become a public charge there, since he probably could not go back to Alaska at his own expense to seek compensation under Alaska's act. In other words, a major purpose of compensation legislation is to prevent the throwing of such injured workmen on local charity, and therefore California had a highly relevant interest in forestalling that event by utilizing its own compensation law.

Any impression that locus of injury was alone insufficient to support coverage was dispelled in 1939 by Pacific Employers Insurance Co. v. Industrial Accident Commission. ${ }^{63}$ The relative sharing of the

61. Alaska Packers Ass'n v. Industrial Acc. Comm'n, 294 U.S. 532 (1935). The significance of this case went far beyond the field of workmen's compensation. It marked the beginning of the end of rigid conceptualism in conflict of laws generally, and introduced the new approach based on legitimate state interests. Professor Brainerd Currie stressed this, stating:

In 1935, in Alaska Packers Association v. Industrial Accident Commission. Mr.

Justice Stone, writing for a unanimous Court, explicitly employed an analysis in terms of state interests to decide a question of the applicability of state workmen's compensation statutes under the Due Process and Full Faith and Credit clauses. With this event, the methods of sociological jurisprudence were at last made accessible to the discipline of conflict of laws. B. CURRIE, SELECTEd ESSAYS ON CONFLict OF LAws 201 (1963).

62. Pierce v. Foley Bros., 283 Minn. 360,168 N.W.2d 346 (1969). In an action to enforce a compensation award made in Oklahoma, the Minnesota Supreme Court held that an employment contract entered into in Oklahoma between a Montana employer and an Oklahoma resident provided sufficient contacts for Oklahoma to have jurisdiction of an injury sustained in Montana, where he had worked pursuant to the contract. Cf. Woodward v. J.J. Grier Co., 270 S.W.2d 155 (Mo. Ct. App. 1954). The court held that where the law of the state of contracting provides that the parties can contract as to coverage, the Alaska Packers case is inapplicable, because the California act stated that no contract shall exempt the employer from liability. Hence, where a Missouri employment contract provided that the law of the place of injury should apply, Missouri was without jurisdiction to award benefits for an injury in Wyoming.

63. 306 U.S. 493 (1939). 
relevant factors listed above was the same here as in Bradford: the place of injury was California; everything else was in Massachusetts. The trip to California was a brief and temporary one. Yet, this time the Supreme Court approved California's application of its act. It even went so far as to say that "few matters could be deemed more appropriately the concern of the state in which the injury occurs or more completely within its power" than "the bodily safety and economic protection of employees injured within it." ${ }^{64}$ lt also sounded a practical note, once more of realistic relevance to the facts of everyday compensation life, when it pointed out that refusal to apply the California law might require California physicians and hospitals to go to another state to collect charges for medical care.

What little might have been left of Bradford after Pacific Employers was obliterated by Carroll v. Lanza ${ }^{65}$ in 1955 , when the Supreme Court held that the full faith and credit clause does not require the state of the injury to apply its sister state's prohibitory provisions. Here the place of contract and residence of employer and employee were in Missouri. After an injury in Arkansas the employee returned to Missouri for care. The work done in Arkansas was for the prime

64. Id. at 503 .

65. 349 U.S. 408 (1955) (6-3 decision). This decision was followed in Collins v. American Buslines, Inc., 350 U.S. 528 (1956), involving an attempt to press into service another constitutional issue, that of burdening interstate commerce. A bus driver, a resident of California, was injured in Arizona on a regular run from Los Angeles to Phoenix. The state court, after concluding that the bus company operated exclusively in interstate commerce, held that the commerce clause of the Constitution precluded recovery under the Arizona act because the employce was covered by the California statute, and to require his interstate employer to insure in Arizona would place an undue burden on interstate commerce. The Supreme Court reversed, saying:

Whatever dollars-and-cents burden an eventual judgment for claimants in the position of petitioners may cast either upon a carrier or the State's fund, it is too insufficient, compared with the interest of the State in affording remedies for injuries committed within its boundaries, see Carroll v. Lanza, 349 U.S. 408, 75 S. Ct. 804, 99 L. Ed. 1183 , to dislodge state power.

Accord, Agee v. Industrial Comm'n, 455 P.2d 288 (Ariz. App. 1969) lClaimants, residents of Colorado, who were hired in Colorado, were injured while on a trucking run from Colorado to California. The injuries were suffered in Arizona, the employer's business was primarily of an interstate nature. Requirement that the employer secure compensation coverage pursuant to Arizona law was held not to be an undue burden on interstate commerce so as to exempt the employer from the necessity of obtaining such coverage.]; Lavoie's Case, 334 Mass. 403, 135 N.E.2d 750 (1956) (residence and employment contract made in Rhode Island; injury in Massachusetts; compensable in Massachusetts); Mandle v. R.O. Kelly, 229 Miss. 327, 90 So. 2d 645 (1956) (contract and residence of employer and employee in Georgia; injury while on temporary trip to Mississippi; Mississippi act could apply). 
contractor. Missouri bars suits against such contractors; Arkansas allows suit. In holding that suit could be maintained in Arkansas against the prime contractor, the Court said:

[T] Tacific Employers Insurance Co. case teaches that in these personal injury cases the State where the injury occurs need not be a vassal to the home State and allow only that remedy which the home State has marked as the exclusive one. The State of the forum also has interests to serve and to protect. ... Arkansas therefore has a legitimate interest in opening her courts to suits of this nature, even though in this case Carroll's injury may have cast no burden on her or on her institutions. ${ }^{66}$

Before Carroll, the argument might have been attempted that Pacific Employers was distinguishable from Bradford in that the former involved a deliberate expression of public policy of the forum state in the form of enactment of a modern remedial statute, while the latter involved only the common-law tort remedy traditionally available in the state. The defendant in Carroll did in fact rely on this distinction, as amounting to a marked difference in expression of economic and social policy by the forum state. The Court rejected this contention:

That is not in our judgment a material difference. Whatever deprives the remedy of the home State of its exclusive character qualifies or contravenes the policy of that State and denies it full faith and credit, if full faith and credit is due. ${ }^{67}$

The Court emphasized that a state has a legitimate interest in effectuating its public policy whether that policy is expressed in statutes or only in the common law. With matters in this posture, there was no way to avoid disavowing Bradford, which the Court did by stating that in Pacific Employers the Court had "departed" from Bradford.

The existence of a legitimate interest in the injury and its consequences had also been decisively confirmed as the controlling constitutional test in Cardillo v. Liberty Mutual Insurance Co. ${ }^{68}$ This time the employee's residence, the employer's business headquarters, and the original place of hiring were all in the District of Columbia, while Virginia was the site both of the current work, which had been going on for three years, and of the injury. The constitutional right of the District to apply its own compensation law was upheld. It is signifi-

66. 349 U.S. at 412 .

67. Id.

68. 330 U.S. 469 (1947). 
cant that the Supreme Court's entire rationale for this holding consisted of the following line of argument:

\begin{abstract}
A prime purpose of the Act is to provide residents of the District of Columbia with a practical and expeditious remedy for their industrial accidents and to place on District of Columbia employers a limited and determinate liability. . . . [T]he District's legitimate interest in providing adequate workmen's compensation measures for its residents does not turn on the fortuitous circumstance of the place of their work or injury. . . . Rather it depends upon some substantial connection between the District and the particular employeeemployer relationship, a connection which is present in this case. . . . And as so applied, the statute fully satisfies any constitutional questions of due process or full faith and credit. ${ }^{69}$
\end{abstract}

Although, then, there is not a separate Supreme Court case for each of the six potential sources of interest, the general principle is broad enough to cover all but the last - contractual stipulation for a particular statute. The place of injury has the authority of the Pacific Employers and Carroll cases to support its claim. The rest figure in the application of the general test to the Alaska Packers and Liberty Mutual situations. The place where the employment relation is created by contract or actually carried on has an interest in regulating the rights and welfare of employees and the corresponding obligations and immunities of employers. The place where the employee or his dependents reside also has an interest of specific relevance to compensation law; for if the employee is left uncompensated or undercompensated, it is his local community that will have to bear the expense of direct assistance and relief. Finally, the place where the industry is localized has a special interest, in that the burdens and costs of compensation fall most directly upon employers and consumers in the area where the industry is centered.

The opinion of Mr. Justice Stone in Alaska Packers contained some language which might have suggested that the interest of the forum state was to be weighed against that of the foreign state in determining the full faith and credit issue. He said, for example, that one who challenges the right of the forum state to apply its own law "assumes the burden of showing, upon some rational basis, that of the conflicting interests involved those ofthe foreign state are superior to those of the forum."70 Later he said of California: "Its interest is

69. Id. at 476 (citations omitted). See also the passage quoted from the Bradford case in the text accompanying note 60 supra.

70. 294 U.S. at $547-48$. 
sufficient to justify its legislation and is greater than that of Alaska, of which the employee was never a resident and to which he may never return."71

Subsequent cases have made it clear, however, that the test is not whether the interest of the forum state is relatively greater, but only whether it is legitimate and substantial in itself. In Pacific Employers the court said of the process of determining when the forum state must deny rights asserted under its own laws: "But there would seem to be little room for the exercise of that function when the statute of the forum is the expression of [public] policy . . . "72 Carroll spoke only in terms of existence of a legitimate interest in the forum state, not of a superior interest. Indeed, the significance of the case on this point is highlighted by the fact that the dissent argued unsuccessfully for a "balancing" of the relative state interests. ${ }^{73}$ And, of course, the entire development of the successive-award practice under McCartin confirms the irrelevance of "weighing," since if only the state with the greater interest could constitutionally apply its law, it would be logically impossible for two states to make an award for the same injury.

The same language quoted from Alaska Packers might also have left the impression that the relative interests of the state should be weighed on a case-by-case basis, in the light of the particular facts involved. Thus, in Alaska Packers mention was made of the fact that the claimant would probably not go back to Alaska. In Pacific Employers, there was evidence that the claimant actually had hospital and medical bills in California that were unpaid. But Carroll discredited this approach completely, again over the objection of the dissent on the specific point. Under the Carroll facts, since the claimant had returned to Missouri for treatment, the conventional arguments about running up unpaid bills or becoming a public burden were not applicable, if the matter was to be considered on an individual basis. But Mr. Justice Douglas said that the interests of the forum state must be judged "not only in the light of the facts of this case but by the kind of situation presented. For we write not only for this case and this day alone, but for this type of case. . . . Arkansas therefore has a legitimate interest in opening her courts to suits of this

\footnotetext{
71. Id. at 549-50.

72. 306 U.S. at 502-03.

73. 349 U.S. at 417-19 (Frankfurter, J., dissenting).
} 
nature, even though in this case Carroll's injury may have cast no burden on her or her institutions." 74

The irrelevance of weighing interests in compensation cases must be particularly observed to avoid confusion with the controversy in conflicts law generally over the "dominant interest" or "most significant relationship" theories of choice of law. The conflicts problem in compensation law, as stressed at the outset, is normally not a choiceof-law question at all, since the forum can apply only one statute, that of its own state, and there is thus no occasion or opportunity to engage in a choice of law. The only "choice" the forum has is to grant relief under its own statute or to deny relief altogether. With that pair of alternatives, it is easy to see why some substantial interest should suffice, without worrying about its relative weight when compared with the interests of foreign states.

When it was stressed above that the only ground relied on in Liberty Mutual was the legitimate-interest argument, this was done for the specific purpose of indicating that several other distinctions and arguments, which figured quite prominently in earlier opinions, seem to have lost their relevance. There was quite a lot of importance in Bradford, Alaska Packers, and Pacific Employers attributed to the question whether the foreign statute purported to be exclusive, since the first inroads into the Bradford doctrine had been made by a distinction turning on this question in Ohio v. Chattanooga Boiler \& Tank $C_{0}{ }^{75}$ which had held that no question of full faith and credit arises at all if the statute of the foreign state is not intended to be exclusive of remedies in other states, since, if the foreign state does not claim exclusive jurisdiction, it naturally is not offended if another state takes jurisdiction. But when, as was assumed in most of the other cases, the foreign state's statute was exclusive, this was offset by saying that the exclusiveness could be defied by the local state if the foreign statute was "obnoxious" to local policy. ${ }^{76}$ Obnoxiousness was readily found, ${ }^{77}$ however, and presumably could be said to exist

74. Id. at 413.

75. 289 U.S. 439 (1933).

76. For an opinion dealing in detail with this issue, see McKane v. New Amsterdam Cas. Co., 199 So. 175 (La. App. 1940).

77. The possibility that California doctors might have difficulty collecting their bills in Massachusetts was the "obnoxiousness" relied on in the Pacific Employers case. Pacific Employers Ins. Co. v. Industrial Acc. Comm'n, 10 Cal. 2d 567, 75 P.2d 1058, 1063 (1938). 
on the mere ground that the foreign statute's benefits were inferior ${ }^{78}$ or less conveniently available to the claimant. Oddly enough, the only case in which there was a deepseated policy difference between the two statutes was the one case in which "obnoxiousness" was found to be absent-Bradford.

Beginning with Liberty Mutual, the word "obnoxiousness" disappears from the lexicon of compensation conflicts, so far as the Supreme Court is concerned, and in Carroll the subject is not even considered.

Since $M c$ Cartin has recognized that the ordinary exclusivecoverage clause does not assume to be exclusive of out-of-state compensation remedies, this entire aspect of the subject may now apparently be written off as an approach to the problem which proved to be much too artificial and technical to meet the needs of compensation administration-a conclusion confirmed by the Supreme Court's complete ignoring of the issue in the Liberty Mutual and Carroll opinions.

\section{Impracticability of Single-Jurisdiction Rule}

To summarize, the entire complicated story unfolded in this article. It opens with a peaceful picture of state courts unvexed by misgivings about full faith and credit or successive awards; next shows the abrupt incursion of the Supreme Court, which then presided over a period characterized by intricate legal controversy; and concludes with the virtual withdrawal of the Supreme Court from the area, leaving matters almost exactly as they would have remained had the Court not intervened. ${ }^{79}$

This is not to say that this whole field of law was the by-product of needless meddlesomeness; on the contrary, it was probably the result of a laudable desire to impose some kind of uniformity on the undisciplined jungle of state rules that had emerged from the different statutes and decisions. The Supreme Court was the only power that could do the job, if the job could be done at all; and it evidently thought that it might gradually, by a series of constitutional holdings,

78. Obnoxiousness on the ground of smaller benefits was used as a supporting ground in Hudson v. Kingston Contracting Co., 58 N.J. Super. 455, 156 A.2d 491 (Mercer County Ct. 1959).

79. There is a striking parallelism between this cycle and that of the rise and fall of the Supreme Court's attempt to demarcate the line between the Longshoremen's Act and state compensation acts by Constitution-based doctrines. See LARSON $\S \S 89.20$ to 89.60 . 
be able to construct a set of overriding principles under which one could eventually say in any given combination of facts, "This case falls within the statute of State A, and no other." But it was not to be. The diversity between states in their statutory and decisional laws had gone too far, and working uniformity could never have been achieved without a simultaneous amendment of all state statutes so that each was the perfect complement of the other. The achievement of such statutory coordination is, of course, entirely improbable; but even if it were possible, there is serious doubt whether the states would find it desirable. The low-benefit states might fear that the operation of a uniform rule would put unpredictable high-benefit burdens on its employers, while the high-benefit states might fear that in certain combinations of facts employees in whom they have an interest would get an unacceptably low level of compensation.

The only uniformity to be looked for, then, is the uniform right of all states having a legitimate interest in the injury to apply their own diverse rules and standards - separately, simultaneously or successively. 